\title{
PRÁTICA PEDAGÓGICA: UM PROCESSO CONTINUO DA CONSTRUÇÃO DA PRAXIS DOCENTE
}

\section{PEDAGOGICAL PRACTICE: A CONTINUING PROCESS OF TEACHING PRAXIS CONSTRUCTION}

\author{
Rubenice Maria de Freitas ${ }^{1}$; Cristiane Maria dos Santos Costa ${ }^{2}$; Andréa Alice \\ da Cunha Faria ${ }^{3}$; Gilvânia de Oliveira Silva de Vasconcelos"; Vinicius Santos Gomes \\ da Silva ${ }^{5}$ \\ DOI: https://doi.org/10.31692/978-65-991061-7-0.465-468
}

\section{INTRODUÇÃO}

Ser professor (a) vai além de estar em uma sala de aula, é desafiar-se todos os dias, levantar a cabeça e continuar trilhando esse caminho, pois “a educação não é só ciência, mas é também arte" (GADOTTI, 2003, p.41). Em outras palavras, não adianta ser o mais inteligente de todos se o indivíduo, enquanto docente, não tiver a sensibilidade de compreender que é preciso ir além, que é preciso utilizar metodologias diferentes, desenvolver habilidades para estimular e clarear dúvidas, incluindo os sujeitos como membros ativos do processo de aprendizagem. "As propostas educativas devem favorecer a inserção do sujeito no mundo, em contraposição a um modelo de adaptação e objetivação desse indivíduo em um contexto de vida determinado pela História" (GONZAGA \& OLIVEIRA , 2012).

É preciso compreender o verdadeiro papel do professor enquanto facilitador do processo de construção do conhecimento e saber como desempenhar sua prática pedagógica sem esquecer o verdadeiro sentido de educar. Porém essa reflexão não deve ocorrer de forma unilateral, mas sim de forma conjunta assim como afirma Gadotti (2003) quando diz que o ato de educar é complexo, e o êxito do ensino não depende tanto do conhecimento do professor, mas da sua capacidade de criar espaços de aprendizagem, vale dizer, "fazer aprender" e de seu projeto de vida de continuar aprendendo. Esse projeto de vida que se estrutura durante o decorrer do tempo se remete a um indivíduo, porém o mesmo atinge indiretamente vários sujeitos da sociedade, pois é importante ter claro que a educação é um processo que ocorre em parceria entre sociedade, família, e o educador, todos buscando uma educação de qualidade.

No entanto, muitos são os desafios -enfrentados durante esse percurso, dentre eles, a postura e a conduta do professor são sempre observadas pela sociedade. Uma vez que se tenha

\footnotetext{
${ }^{1}$ Bacharelado em Agronomia, Instituto Federal de Pernambuco, rubynha1995@ gmail.com

${ }^{2}$ Bacharelado em Agronomia, Instituto Federal de Pernambuco, cristianemscosta01@ gmail.com

${ }^{3}$ Doutora em Educação, Universidade Federal Rural de Pernambuco, andalice@uol.com.br

${ }^{4}$ Doutora em Educação, Universidade Federal Rural de Pernambuco, gilvania.ov@ hotmail.com

${ }^{5}$ Doutor em Agronomia-Ciência do solo, Instituto Federal de Pernambuco, Vinicius.agro2008.1@gmail.com
} 
a imagem do docente enquanto mediador do conhecimento e referência, a responsabilidade que se confere a este profissional vai além de suas atribuições, aumentando a exigência por profissionais de excelência. Este sentido este relato tem por objetivo relatar a experiência vivenciada durante o curso de licenciatura em ciências agrícolas em parceria com Instituto Federal de Educação, Ciência e Tecnologia de Pernambuco campus Vitória de Santo Antão, durante o período de 2017.1 a 2018.1, onde foram desenvolvidas atividades de diagnóstico de unidade de ensino, observação de aulas, -laboratórios de ensino e regência.

\section{RELATO DE EXPERIÊNCIA}

Através da realização do estágio pude vivenciar momentos de desafios e aprendizados, que me proporcionaram o desenvolvimento de habilidades para conduzir as situações da melhor forma possível. Sabendo-se que as escolas têm seu ritmo de trabalho e que seus procedimentos e ações são norteadas pelo projeto político pedagógico-PPP, durante o período foi possível desenvolver várias atividades com o olhar diferenciado dentre elas pode-se citar a analise da unidade de ensino, no qual pude verificar como realmente ocorre o funcionamento da escola e se as suas ações estão de acordo com o projeto político pedagógico, no entanto, um dos requisitos que que devem apresentar é a contextualização com a realidade, que na prática é um desafio para muitas instituições, através desta analise pude olhar de forma crítica e construtiva, me desafiando a transformar a visão de aluna em uma visão de professora de forma holística e sistêmica de como ocorriam os procedimentos.

Outra atividade foi à realização dos laboratórios de ensino que consiste no desenvolvimento de uma aula onde os alunos em formação são submetidos a ministrarem passando pela mesma situação de avaliar e ser avaliado. Esta experiência promoveu o aperfeiçoamento da práxis docente, enriquecendo as aulas com ferramentas e promovendo a superação dos limites e dificuldade no desenvolvimento dos laboratórios. As realizações dos primeiros laboratórios foram mais impactantes por ser a primeira vez de vivenciar aquela experiência se tornando um desafio. Como um primeiro contato com a docência trouxe diversas perspectivas como a importância de uma aula com início, meio e fim, o planejamento de tempo e atividades avaliativas, a sondagem do conhecimento prévio, a construção do conhecimento junto com a turma. segundo laboratório, realizado durante o Estágio Curricular II foi uma experiência fundamental para clarear as fragilidades que ainda tinha e pontos fortes, que deu mais sentido à prática docente. Esse momento fez refletir como a prática pedagógica em sua execução é desafiadora e compromissada diante do processo de ensino aprendizagem, pois cabe ao professor criar ou adaptar métodos que estimulem os educando o 
interesse pelo conhecimento, no qual o educador/ educadora mediará nos processos pedagógicos auxiliando o processo de construção- dos conteúdos, fazendo o viés com referências locais.

Durante a_E com a regência, realizada no contexto do Estágio Curricular III foi possível vivenciar o desafio enquanto futura docente, de trabalhar com temas iguais, porém com objetivos distintos, sair da zona de conforto, e compreender a diferença entre uma apresentação de um seminário e a condução de uma aula. Diante do compromisso na transmissão de informação e a veracidade das fontes de informação, foi possível perceber um pouco do tamanho da responsabilidade. A regência na minha vida foi á oportunidade mais esperada e maravilhosa que me aconteceu durante o estágio, pois me identifiquei perfeitamente com aquele ambiente, e tive a certeza que estava seguindo a profissão da minha vida, o medo de não conseguir responder os questionamentos dos alunos, o nervosismo em estar diante das turmas foram aparecendo, mas o desejo de que era aquilo que eu quero para minha vida era e é mais forte.

Pude perceber que mesmo que os temas fossem iguais para algumas turmas, o desenvolver da aula seguia ritmos diferentes, cada turma se apropriava do conteúdo e daquela experiência com intensidade diferente, o olhar e as experiências de vida dos alunos muitas vezes nos momentos em aula, eram os exemplos mais vivos que poderiam ser utilizados, e isso me remetia aos que sempre foi discutindo em sala na faculdade a importância da contextualização, para maior clareza do conteúdo levei experimentos e elementos para facilitar o entendimento e a facilidade com algumas técnicas de manejo, e utilizando esse tipo de ferramenta, percebi que os alunos se sentiam mais ativo dentro do processo de construção do conhecimento.

\section{CONSIDERAÇÕES}

O estágio foi uma experiência de suma importância que contribui para minha formação profissional, no qual me deparei com situações que não me desafiava a ir cada vez mais em busca de conhecimento, sendo essa uma busca interminável, foi através dessa experiência que tive a certeza que estou seguindo o caminho certo e que a docência é a minha missão social, profissional e pessoal. As atividades foram fundamentais na contribuição da minha práxis docente na qual consiste em um processo continuo, que vai se aprimorando com as experiências da vida. 


\section{REFERÊNCIAS}

GADOTTI, M. Boniteza de um sonho ensinar-e-aprender com sentido. Feevale. Novo Hamburgo,, 2003.

GONZAGA, A. M.; OLIVEIRA, C. B.; As contribuições de Paulo Freire a uma educação científica na formação docente. Rev. Eletrônica do Curso de Pedagogia do Campus Jutai, UFG, v.1, n.12, 2012. 